\title{
FIVE
}

\section{Local planning in Belgium: A myriad of policy styles?}

\author{
Ellen Wayenberg, Min Reuchamps, Marine Kravagna and Catherine Fallon
}

What policy style(s) does local government display in Belgium? This seemingly straightforward question does not have an easy answer. After all, the country is renowned for its institutional complexity and thickness [[meaning of thickness? impenetrability?]], two features that have a significant impact on local government's way of working. In the wake of state reforms, the federal government granted the three Belgian regions (Walloon, Flemish and Brussels) key competencies over the cities and municipalities standing on their territory (Deschouwer and Reuchamps, 2013). In 2001, regions were even given powers over and above those granted in the basic local government legislation, regulating to a large extent local political and administrative institutions and practices. A new and influential layer of central government has thus been created: all regions have grasped their new powers to introduce policy tools and instruments on the local level, according to their own needs and policy orientation (Wayenberg et al, 2011). This federalisation process added diversity between cities and municipalities that were already very heterogonous in size, financial status and political dynamics, to name but a few of their basic characteristics (De Rynck and Wayenberg, 2013). As a result, local government in the three Belgian regions now operates under different regulatory frames.

This chapter explores whether local government in Belgium displays a specific style of policy analysis. To this end, we use a two-level comparative analysis that allows us to shed light on local policy analysis in the context of the specificity of the Belgium's regions. The first level is a comparison of the Flemish and the Walloon regions. The focus on them is not only a matter of size, as Flanders and Wallonia respectively count for $308(52 \%)$ and $262(45 \%)$ of the 589 Belgian municipalities, but also a matter of policy analysis. Indeed, they represent the country's two main administrative traditions, being located in the Dutchspeaking north and the French-speaking south. Both have also made use of their competency to legislate on local government political and administrative institutions and practices, and have promulgated local government legislation to this end. That is not the case with the Brussels-Capital Region, which accounts for 19 municipalities (3\%) still functioning according to the Belgian legislation of 1988 (De Rynck and Wayenberg, 2013). The case of Brussels will therefore not be covered by this chapter nor will the peculiar case of the nine Germanspeaking municipalities that are attached both to the Walloon Region and the German-speaking community (Bouhon et al, 2015). 
As such, we aim at finding out which policymaking tools and instruments are currently in use at the local level and which are emerging, via a thorough document analysis of local government legislation in both regions. The second comparative level is a case study of two local governments with the aim of verifying the implementation of the new regional tools and instruments. Are these reforms actually embedded in local government practice, thus shaping local policy style? To this end, we consider one Flemish and one Walloon local government, Deinze and Gembloux respectively. These cities are quite similar in terms of their main institutional features: both are medium-sized, financially healthy and have been governed since 2006 by the same parties. They are neither well-known 'success stories' nor criticised as 'worst cases' as far as planning practice is concerned. Rather, they are supposed to be 'business as usual' stories that could provide meaningful insights regarding local policy analysis in Belgium. These two case studies are thus suitable to gather context-rich insights into local government's style(s) of policy analysis and the interrelations between local actors and the processes of governance. This data highlights any gaps between local practices and regional injunctions, as well as the differences between the two regions. Before turning to the two-level comparative analysis, we start by clarifying the policy-style concept that is central to our analysis.

\section{Policy style and local government}

Up until now, the concept of policy style has rarely been used as a heuristic tool to understand policy analysis in local government. Rather, it is commonly applied to the national level for comparing policy communities within as well as between political systems in terms of commonalities in their policymaking patterns (Richardson et al, 1982; Parsons, 1995; Knill and Tosun, 2008). The concept provides a simple and effective framework for comparison. An overview of the literature suggests that simplicity springs from the limited variance on standard operating procedure taken into account to grasp a government's policy style. The work of Richardson and colleagues seems to have set the tone in this regard (1982), promoting the style concept and serving as a starting-point for various typologies ever since. According to Richardson et al (1982), only two dimensions are needed to satisfy the concept's operationalisation [[applicability?]]. The first one covers how policymakers acknowledge societal issues and their approach to problem analysis. The second concerns their relative autonomy vis-à-vis other actors involved in policymaking and implementation. Do policymakers seek consensus among these parties or simply impose their decisions on them? Together, both dimensions give rise to a framework that has been used repeatedly to compare national governments according to their pattern of policymaking (Freeman, 1985; Bovens et al, 2001).

The effectiveness of the framework can be ascribed to its ability to identify a government's operating procedure from a policy-analytical point of view. According to the literature, there are several ways of performing policy work 
and each way can be associated with one or more specific clusters of activity that policy analysts perform. Clarifying as well as developing values and arguments is one of these widely recognised clusters. Typically, these activities are performed by policymakers who are primarily concerned with the social construction of policy problems, policy discourses and the politics of the policy process. In 2000, Radin labelled those policymakers as post-modern in their performance, a label that falls under the anticipatory style (2000). A second activity cluster is characterised by a reactive way of working, typical for policymakers who spend their time mainly on researching and analysing facts, causes and effects. At least to a large extent, they assume the world to be empirically knowable and measurable and that policy knowledge should and could be provided as complete and unbiased as possible, capable of withstanding scientific scrutiny. According to Walker [[not in refs]], these activities and assumptions typify traditional policy analysis (2008).

In addition these two activity clusters, that is to clarify/develop values and arguments and to research and analyse, four others are defined by Mayer and colleagues (2004). All of them can be associated with the operating procedures of Richardson's second dimension as they refer to interactions and power relations between government and other actors involved in policymaking. As mentioned earlier, a government can impose policy solutions in a top-to-down hierarchical style. Policymakers will then (have to) act strategically as well as design clear policy processes as main clusters of activity. Alternatively, a government can opt for a bottom-up inclusive and participatory style and seek consensus with other key parties involved. Policymakers' main cluster of activity will then (have to) consist of democratising policies and/or mediating between parties. As visualised in Table 5.1, each cluster can be related to a specific policy style. In association, they provide an understanding and comparison of the main governmental policy $\operatorname{pattern}(\mathrm{s})$.

Table 5.I: Policy styles and main clusters of policy-analytical activity

\begin{tabular}{|l|l|l|}
\hline & $\begin{array}{l}\text { Anticipatory } \\
\text { To clarify/develop (new) } \\
\text { values and arguments }\end{array}$ & $\begin{array}{l}\text { Reactive } \\
\text { To research, analyse and develop } \\
\text { knowledge of problems and solutions }\end{array}$ \\
\hline $\begin{array}{l}\text { Consensus seeking } \\
\text { To democratise policies and/or to mediate between } \\
\text { parties involved in policymaking to unveil groups' } \\
\text { standpoints and worldviews and to support mutual } \\
\text { understanding }\end{array}$ & Post-modern & Communicative \\
\hline $\begin{array}{l}\text { Coervice } \\
\begin{array}{l}\text { To act strategically to integrate the interests of actors } \\
\text { involved and/or to design clear policy processes }\end{array}\end{array}$ & Strategic & Traditional \\
\hline
\end{tabular}

Source: Richardson et al (1982); Mayer et al (2004) 
Applying this framework at the local level helps to reveal the diverse configurations of local actors and their impact on policy style. However, it cannot be applied without analysing the contextual conditions - quite important in policy analysis, particularly when the issue at stake is 'ambiguous' with no clear-cut, defined solution (Matland, 1995). The variety of local conditions in Belgium should therefore not be underestimated: the power and diversity of local (un)elected actors depend on long-term historical and institutional trends as well as on the recent remodelling of political forces, due to the socioeconomic and demographic transformations. This variety is examined in more details in the next section.

\section{Local government in the federal state of Belgium}

According to the Belgian constitution, local government can take whatever initiative it wants as long as it is beneficial to local interests and no other government has legal responsibility for the field of action concerned. As such, each local government can operate autonomously on its own territory, a principle that is institutionally reflected in the direct election of its legislative council. However, the Belgian reality of local policymaking is far from one of (full) local government autonomy and power. After all, throughout successive rounds of state reform, Belgium has evolved into a state of complexity with an additional governmental layer created and active ever since (Wayenberg et al, 2010). In particular, two types of sub-central non-local government have thus been installed: three regions on the one hand - the Brussels, Flemish and Walloon regions - as socioeconomic entities with competency over hard policy domains such as housing, transport and spatial planning, and three communities on the other - the Flemish-, French- and German-speaking communities - as language-based entities dealing more with soft policy fields such as education, culture and youth policy. Their respective territory does not fully coincide. ${ }^{1}$ On top of this, there is no clear hierarchy of legal norms in the trade-off between federal government and regions/communities. Put differently, the latter cannot be overruled by their federal counterpart within their fields of competencies. In those fields, they act as the only national government while in other fields - including social and economic matters - policymaking is the result of their bargaining with federal government. From local government's point of view, the overall impact of Belgium's federalisation process is straightforward: a new layer of central government has thus been created as regions and communities have been steering their local counterparts in the respective territory- and person-oriented [[population-oriented?]] policy fields for which they hold competency. Apart from the resulting centralisation of the local sphere of action, the regions have also gradually been granted specific key competencies with regard to the local government system on their territory. These competencies include central supervision over local government (1980), the municipal fund (1988), intermunicipal cooperation (1993) and, most importantly, local government's basic 
legislation (2001), thus turning regions into Belgium's main central governments from the local point of view (De Rynck and Wayenberg, 2009).

In this chapter, the two cities selected as 'case studies', Deinze and Gembloux, are positioned in the framework presented above. To this end, each case study starts with the discussion of the major reforms that the regional government has introduced over the last years (first level) and that affect local policymaking. They include financial repercussions concerning the expenditure and revenue dimensions of local government operations, and structural ones dealing with the number, type and size of municipalities, quasi-municipalities and local specialpurpose bodies. However, first and foremost, the chapter considers the reforms that have stimulated local elected councils and/or administrative units to adopt new or renewed ways of policymaking. These reforms are discussed through interviews with a selection of political and administrative policymakers of the two cities under study (second level). This allows an appreciation of the social embeddedness of these reforms as genuine instruments of local policy practice/ style as well as the specific local issues these new tools may (or may not) address. The Flemish and Walloon cases are subsequently presented, followed by a thorough comparison to find out whether there is ground to assume a specific local style of policy analysis in Belgium.

\section{Local policy analysis in Flanders}

\section{Regional setting}

In Flanders, recent modernisation of local government is mainly the result of injunctions from the Flemish regional authority. As explained earlier, the latter gained key competencies vis-à-vis the local level during various rounds of Belgian state reform. And it has used these powers consistently to steer its local counterpart towards performing more efficiently and effectively, and with greater customer focus, within a (re-)new(-ed) public management (NPM). Over the years, strategic planning has been one of the Flemish government's main instruments to this end. Initially, in the early 1990s, planning was introduced as a prerequisite for Flemish subsidisation of local government in a select number of policy fields, including social, mobility and environmental policy. By the turn of the century, it had evolved into standard practice in practically every field of local policymaking, amounting to more than 30 different sectoral policy plans being drafted at the local level (Vlaamse Regering, 2006).

Repeatedly, Flemish local governments have complained about this practice resulting in too much 'planning burden'. In essence, their complaints are threefold (VVSG, 2006). First, they have criticised the high number of regional planning and reporting requirements imposed in a range of policy fields. In 2007, each local government was drafting up to 27 different policy plans, often forcing them also to adopt the Flemish intra-organisational structure (Dienst Wetsmatiging [[spelling? Wetmatiging in refs]], 2007). Second, these requirements have often been 
criticised for being too detailed. In various fields, they leave little or no policy leeway for local government. The latter is thus forced to act as a regional agent in order not to be deprived of financial means that are locally deemed essential for any policymaking at all. Third and finally, the divergence among planning requirements causes local distress. These requirements differ substantially from one policy field to another with regard to - among other things - policy duration, result orientation and monitoring. And these sectoral differences hinder every local government in efforts to join up its plans.

Since the mid-1990s, subsequent Flemish governments acknowledged the local planning problems and each in turn took steps towards their remediation. On 20 June 1995, the first directly elected Flemish government took office. In its coalition agreement, this government expressed its intention to work with local government to achieve optimal intergovernmental relations (Vlaamse Regering, 1995). On 8 March 1999, it finally signed a pact with the local representative organisation to this effect. The pact contained 63 action points, including one to harmonise Flemish sectoral subsidisation vis-à-vis the local level. However, little implementation took place as the Flemish legislature ended a few months later. The divergent subsidisation requirements as well as their overall number were also at stake during the so-called core task debate for Flanders. This debate was launched by the newly installed Flemish government in 1999 (Vlaamse Regering, 1999). From the beginning, two questions were at the fore, that is, what tasks does the Flemish government have vis-à-vis the private sector and how should the governmental tasks be divided among the Flemish, provincial and local administrations as the three democratically elected layers of government? To deal with this second question, numerous intergovernmental debate groups were set up across all sectoral policy fields. Their activities resulted in the signing of the so-called 'core task agreement' on 25 April 2003 between the Flemish government and the provincial and local representative organisations. Among other actions, these parties thus agreed to make an inventory of all Flemish intergovernmental subsidies with a view to harmonising their requirements concerning sub-central planning and reporting as well as reducing their overall number. But again, this agreement ended in the second half of the Flemish legislative term and few concrete actions to lift the local planning burden were taken at that time.

The situation somewhat improved after the 2004 elections. A new Flemish government took office on 20 July 2004. In its coalition agreement, this government immediately announced an audit of its sectoral planning and reporting requirements vis-à-vis the local level with the purpose of simplifying and reducing them (Vlaamse Regering, 2004). To this end, two research reports were ordered and written, by academics and civil servants respectively. Both of them contained concrete recommendations to harmonise planning and reporting requirements across sectors or even abolish them altogether. Next to this, there was the critical report of the advisory Committee on Efficient and Effective Government that the Flemish government had installed in its endeavour to evolve into one of Europe's five top regions by 2020 . The committee report made a clear plea for a drastic 
reduction in the number of sectoral planning and reporting requirements to an absolute minimum as well as for their mutual integration into an all-embracing legislative framework (Commissie Efficiënte en Effectieve Overheid, 2009). And precisely these ideas were central to the way in which the next Flemish government tackled the local planning burden.

This government took office on the 13 July 2009. In its coalition agreement, it clearly committed itself to unburdening its local counterparts from unnecessary planning and reporting (Vlaamse Regering, 2009). Central to this was the Flemish idea of a Policy and Management Cycle (PMC) in local government aligned to the six-year term of the latter. After all, that six-year cycle of planning, budgeting and reporting would encompass all local policy fields and objectives, thus reducing the necessity for and number of separate sectoral plans at the local level. Moreover, the Flemish government would restrain from excessive top-down interference in local government PMC and would confine its involvement to controlling outcomes. [[edit OK?]] Finally, the accompanying planning and reporting requirements would apply to all policy fields, thus preventing their mutual divergence. In sum, the PMC planning reform holds the key to a lower local planning burden, at least from the Flemish point of view.

The PMC was legally enforced on 25 June 2010 (Vlaamse Regering, 2010). The Flemish government then altered the basic local government decree to require every municipality to adopt a six-year planning, budgeting and reporting cycle. However, this legislative step alone was deemed insufficient for any meaningful reform of local planning in Flanders. This was the view taken, among others, by the then Committee for Efficiency Gains in Local Government (CEGLG), a Flemish advisory committee including local representatives. In its view, the success of the PMC also relied on a drastic turnaround in Flemish subsidy practices. After all, the planning burden on local governments intrinsically springs from the numerous, detailed and divergent requirements of Flemish departments and agencies operating in accordance with central directives in various areas. There was a danger that the PMC reform might even increase the local burden by introducing yet another cycle of policy planning on top of all the rest, hence the CEGLG's urge to add a sectoral slant (Commissie Efficiëntiewinst voor de Lokale Besturen, 2010). Sensitive to this concern, the Flemish government drafted an Act on the local planning burden aimed at stipulating clear principles for future sectoral subsidisation. It took more than a year - until 15 July 2011 - before that second legislative step was taken (Vlaamse Regering, 2011). Notwithstanding various alterations to its principles, the Act was approved in parliament and the number of Flemish regulations within its scope were drastically reduced. Initially, the Flemish government intended to streamline 14 sets of sector-specific directives concerning local planning. Finally, only ten remained and were redrafted between November 2011 and September 2012. These Flemish regulations were thus integrated with the planning burden requirements before the local elections of October 2012 that signalled the start of the first (and current) six-year term of PMC implementation. In no particular order of importance, the areas of policy 
areas affected are sports, integration, urban affairs, developing aid, youth, welfare, culture, heritage, education and service economy. [[edits OK in this para?]]

What are the specific principles now guiding local planning reform in these fields (Dienst Wetsmatiging, 2010)? As noted earlier, the PMC places new planning, budgeting and reporting requirements on local government. These include drafting a six-year strategic policy plan and annual evaluation reports. All documents resulting from the PMC should serve local needs as well as local government applications for sector-specific subsidy. Separate local documents would undermine Flemish administrations' 'use of PMC' as the first principle embedded in the Act on the local planning burden. The second principle aims at 'more local autonomy'. Seemingly contradictory at first sight, the Act subscribes to the Flemish use of top-down subsidies for the purpose of achieving policy objectives. But in doing so, each Flemish objective should aim to grant local government enough leeway to align its intentions with specific local needs and objectives. After all, policy made at the local level ought to be local. Accordingly, the third principle of the Act requires the Flemish government to 'shift from input- to output- and outcome-oriented influence and control' [[edit OK?]] at the local level. Consequently, a subsidising administration may regulate its local counterpart primarily in terms of local output and outcomes, but may no longer tie subsidies to specific local input actions, such as the appointment of an official with particular qualifications or the design of the local organisational structure. [[edits OK?]] Local government has now been granted the full prerogative in such cases. However, the same cannot be said when it comes to the involvement of local stakeholders. While the fourth planning burden principle underlines 'the importance of local participation', it clearly preserves the Flemish prerequisite of requiring local government to account for the involvement of specific local stakeholders throughout the PMC. The fifth and final principle concerns 'cofinancing'. The Flemish no longer has an obligation to cover all costs arising from the implementation of its policy objectives at the local level. Local government is now expected to invest up to the amount of any subsidy granted. [[edits OK in this para?]]

Box 5.1 lists the five principles of the Flemish Act on the local planning burden. All of them are instrumental in the quest towards greater policy integration and coordination at the local level. These targets are typical within the so-called postNPM period, the ongoing era of administrative reform since the early $2000 \mathrm{~s}$.

The next section examines how local policymaking works in practice, using Deinze as an example of a city operating under the Flemish regulatory framework of local planning reform. 


\author{
Box 5. I: Principles of Flemish subsidisation according to the $20 \mathrm{I} \mathrm{I}$ \\ local planning burden Act \\ Use of the PMC \\ More local autonomy \\ A shift from input-oriented to output- and outcome-oriented influence and control \\ The importance of local participation \\ Co-financing
}

\title{
The case of Deinze
}

Deinze is a medium-sized city of approximately 30,000 inhabitants, located in the province of East Flanders near the provincial capital of Ghent. The city has no specific problems or exceptional assets and does not deserve specific attention by the regional authorities, which is why we have chosen it as a case study. The local politico-administrative structure is large enough to require efficient forms of organisation. Deinze is governed by a coalition of Christian Democrats (CD\&V) and Liberals (Open-VLD+) that was re-elected in October 2012 for a second term. Shortly after the elections, the PMC was introduced locally as required by the Flemish local government decree (Stad Deinze, 2013). With a view to thoroughly canvassing the local area as part of the PMC, the city and the public centre for social welfare jointly organised a survey of 5,000 inhabitants. ${ }^{2}$ To complement this exercise, several citizen focus groups took part in the project Als je 't mij vraagt ('If you ask me'). The city appointed an extra staff member to carry out these initiatives. It also refrained from hiring consultants for other stages of the PMC, motivated by a willingness to get to know and work with the planning tools that the Flemish government had introduced locally. As such, an intense but very informative consultation period took place lasting over a year and ending successfully on 19 December 2013 when the city council approved the resulting multi-annual policy plan and a balanced budget for 2014-19 (Stad Deinze, 2013). The plan contains 13 policy goals. All are embedded in various programmes and action plans grounded in information that was gathered via the canvassing exercise. They all reflect Flemish policy priorities and were approved by the city administration, which added more detail into the PMC documents than was legally required. After all, these plans and reports form the basis of Deinze's future and deserve to be fully evidence-based. [[edits OK in this para?]]

What policy style(-s) did Deinze demonstrate during the process of drafting its policy plan and budget? By approaching its citizens through a survey and focus groups, the city initially aimed to expand its knowledge of its inhabitants' needs and desires. Launching (new) policy ideas was not a primary objective. First 
and foremost, the city took a reactive stance and looked backwards in order to better understand what was already 'alive and kicking' in its own community. In retrospect, the survey and focus group results were not really surprising. As the mayor put it:

\begin{abstract}
"The answers affirmed that we - as policymakers of Deinze - basically want to move in the same direction as our citizens. For example, we have wanted a cultural centre on our territory for a long time now and clearly, that same desire lives among our citizens. Mobility is another issue that really concerns people but of course, we already knew that as well."
\end{abstract}

Nevertheless, both of these exercises were locally regarded as very valuable, not least because of their ability to temporarily bridge the gap between policymakers and citizens. The focus groups turned out to be particularly instrumental in this regard. Eleven focus groups were organised between February and May 2013. Each focus group gathered six to 10 residents to jointly discuss and propose innovative solutions to improve the city's way of working. One area singled out for improvement was the city's e-services. Although it was well known that the service was little used, the reasons for this were not fully understood. By getting several groups to focus on this issue, the city actually gained in more ways than one. As well as gathering ideas about how to make its e-services more citizen-friendly and accessible, it could use the focus groups as a test-bed for the workability of the proposed solutions, which passed the first - and critical - customer test. [[edits OK?]] Of course, not all policy ideas launched via the survey and focus groups were adopted by the city. In the words of the city manager:

\begin{abstract}
"Some ideas - such as digging a tunnel under the town centre to solve the mobility problem - might be interesting but they are just too expensive and not feasible to realise. And finally, it is our job to make ends meet."
\end{abstract}

By explicitly opting for dialogue with its citizens, the city had more time to explain its policy standpoints, which in turn meant that citizens could gain greater understanding of (the limitations of) its policy work. [[edit OK?]] Overall, the city clearly adopted a communicative stance during the first stage of drafting an allround and financially feasible policy plan for the upcoming legislature. It actively researched and analysed its citizens' needs and desires, and combined this with a consensual way of working by opting for negotiation and dialogue instead of just unilaterally translating the knowledge gained into a series of goals and actions.

However, throughout the policy implementation period, the city also showed signs of operating according to another style. The mayor's attitude towards the so-called 'blue-bike' project is indicative of this. Deinze had an initiative of renting 
bicycles daily at a very low rate in order to reduce the number of cars passing through the city. A great supporter of the project, the mayor admitted:

"One day, I counted the number of people that I still would have to convince to start cycling in our city, given the fact that I only have five more years to go. More than 150 a day. Of course, that is not possible. But that does not stop me from promoting this idea another 200 or even 300 times, at every possible occasion. Because that is what you have to do: you have to believe and defend your beliefs wherever and whenever you can."

Here the mayor explicitly takes on an anticipatory approach in addition to a merely reactive one. According to the city manager, this stance is typical:

"Local politicians are much more citizen-focused. And that is common practice. After all, politicians are judged by the citizen whilst we are not. And so, they are the ones having to explain the choices that are locally made".

But for their part, local administrators do not just stand aside but often play a crucial part in preparing political speeches and making sure that policy ideas are highlighted at the right time and place. In short, they turn out to be indispensable to the implementation process once ideas have been adopted. And in Deinze, this strategic style increasingly complemented a primarily communicative way of working once the planning process began to evolve from the kick-off phase into its current executive stage.

\section{Local policy analysis in Wallonia}

\section{Regional setting}

In 2004, the Walloon government defined the conditions of local governance in a unique document, the Code of Local Democracy and Decentralisation (Code de la démocratie locale et de la décentralisation, or CDLD), which applies to the organisation of municipalities and of provinces, the designation of governing bodies and the management of local policies. Matagne et al (2011) observe a twofold change stemming from the introduction of the code. On the one hand, it enlarges the sectors of intervention of local authorities [[sense? it increases local authorities' powers of intervention?]]. On the other hand, it opens up the local governance to the citizens and civil society. Thus, the candidate with the highest number of votes in the list with the highest number of votes in the majority coalition [[sense?]] is directly elected as mayor (CDLD, art. 1123-4, par. 1, al. $1^{\text {er }}$ ). A new principle also appears, that of 'constructive mistrust', which reinforces the democratic accountability of the executive: one (or more) member 
of the executive body can change during the legislature on the local council's request. Finally, the president of the public social welfare centre (CPAS) acts as a member of the local executive, which supports an increase in transversal policies. Matagne et al (2011) present these transformations as a tendency towards a stronger democracy of and for the public, with a decrease in political parties' power.

In recent decades, the Walloon government has supported the implementation of several new policy tools at the local level, each of them imposing a strategic and participatory implementation pattern. Among them we analyse the Communal Plan for Rural Development (Plan communal de développement durable, or PCDR) and the Transversal Strategic Plan (Plan stratégique transversal, or PST), which contribute to a new framework for local policy analysis in Wallonia. These new instruments (none of them are compulsory) refer to different sectors that usually vary a lot as far as their level of influence over local government is concerned. Nevertheless, they share three important characteristics: they are bottom-up and based on a strategic diagnosis and analysis of the current situation. They are innovative in the sense that they emphasise communal strategic autonomy and support local strategic competencies in policymaking. But the local autonomy is very narrowly framed by the regional government, which defines precisely the local procedural approaches for accessing financial resources, while leaving room for manoeuvre for the municipality to allocate resources to specific, locally defined projects. We propose to use these new tools to highlight the governmental style in Wallonia and to analyse our local case study, the city of Gembloux [[edit OK?]]. This leads to the following twofold question: do these tools influence the local policy style and how do local policymakers and administrations appreciate these new tools with regard to the main characteristics mentioned above?

In 1991, Wallonia adopted egislation intended to support local development policies in a participatory approach that established the Plan communal de développement durable (Godart and Deconinck, 2003). The PCDR comprises a set of coordinated development and planning actions undertaken in rural areas, whose operations are financially supported by the region (up to $80 \%$ ). ${ }^{3}$ The strategic planning (with a vision of up to 10 years) derives from a third-party diagnosis report and thorough public consultation, and establishes a local development coordinated strategy based on a deep analytical, prospective and shared diagnosis of the territory. The main driver behind the definition of the projects to be launched - with large regional subsidies - is the local commission for rural development (Commission locale de développement rural, or CLDR). This group comprises 10 to 30 inhabitants representing different political, economic, socio-professional and cultural sectors and backgrounds. Its mission is to prepare the diagnosis, produce the plan and implement the different projects, with the support of a technical designer. The PCDR dynamics rely strongly on an ascending participatory process of co-construction with the stakeholders and inhabitants, as well as the involvement of technical experts. Management of the CLDR must be outsourced to a regional company specialising in social intervention. This instrument has 
only marginally been modified since 1991 and is still very important for local policy analysis.

In 1999, the regional government presented a new strategic plan, entitled Contract for the Future of Wallonia (Contrat d'avenir pour la Wallonie), developing a strategic vision for the economic rehearsal [[sense? economic performance?]] of the region (De Coster [[spelling? Decoster in refs]] et al, 2003). As a consequence, in 2003, local authorities were required to define their own local Contract for the Future (Van Cauwenberghe, 2003): each entity is asked to develop a strategic vision with reference to the regional priorities. This proposition was met with little support. What the local authorities were waiting for was a new local strategic management system, which would not involve the heavy or complex planning required by the Contract for the Future.

In 2009, the Walloon government launched a new tool for local authority management: the Transversal Strategic Plan (Plan stratégique transversal, PST). This contains the global policy strategy of the commune [[define this term in a footnote for non-French speakers? Not sure there is an exact translation, unless municipality covers it?]] and aims to create a better culture of planning and evaluation (Union des villes et des communes de Wallonie, 2011; Boverie et al, 2013a). ${ }^{4}$ The regional minister in charge of the local bodies proposed developing a pilot action with voluntary local authorities, which were invited to initiate a local planning strategy based on production of a local diagnostic and the definition of transversal local priorities of action. The project aims to establish such an approach for the next local term (2018-24). Half of the communes (132) showed an interest, and 24 were selected to receive specific support during the pilot phase and to test the system. They were asked to finalise their PST and to make the document public, as well as to take part in the development of common tools and management systems to support the new dynamics of policy analysis, implementation, follow-up and evaluation. The diagnostic was mostly written by the local administration with the use of data from a new website designed by the Walloon Institute of Evaluation, Foresight and Statistics.

This strategic tool, close to the Flemish local planning and reporting cycle, is prepared by the local authorities and the local administration in the year after the local elections, with very limited public participation. It combines in the same document internal components and resources (local administration) and the strategies for local policies for the next six years, presenting a comprehensive overview of all local actions and policies, and other strategic or sectoral local plans. At the core of any PST is the political project of the political authorities, which is supposed to be in line with the local diagnostic. These priorities are translated into operational targets and relevant resources.

The writing of the plan itself is based on the involvement of the local executive body (the College) and of the local administration. The political authorities are responsible for drafting the main strategic goals (with reference to questions such as 'What do we want to achieve in the next six years?') and to translate them in relation to available resources - not only local resources and competencies 
within the administration itself, but also external subsidies and support from local partnerships with public or privates bodies. The plan must translate the political vision into operational priorities and concrete actions, taking into consideration the limited resources available (reality principles) and the possible partnerships to be established.

What is new is the internal side of the plan: besides the political projects, the administration itself can design its own strategic vision, in order to manage the requirements imposed by the political authorities as well as to develop modern modes of management. This part of the PST is often presented as a possible 'contract' between the administration and the political authorities: even if it still remains an informal contract, it reconfigures the action of the administration, its forms of cooperation and the modalities of accountability with regular reporting of the achievement of the PST.

In 2013, two new regional laws reformed the status and modes of action of heads of the local administration. ${ }^{5}$ They reinforced the role of the head of administration as general manager (director-general, DG) and head of local staff: their higher status was confirmed by a major salary increase (Durviaux and Fisse, 2015, p 71). These laws launched a compulsory reform of local administration's top management by changing the status of high local civil servants and by redefining the relationship between the local authority and its administration thanks to the setting up of new management tools (Boverie et al, 2013c).

The objective of this reform is often presented as the 'modernisation of the management of local administrations' (Walloon parliament, 2012-2013, p 2), translated into concrete tools for a more transversal and project-based governance. The DG is required to produce a written document for the legislature - the statement of mission (lettre de mission) - outlining how the political objectives will translate into strategic guidelines, operational aims and projects. This document combines an account of strategic policy and an annual evaluation of the DG's objectives with a description of the main political priorities of the College and its own resources and mission [[list ministerial circular in refs; Walloon parliament, 2013, p 37?]]. For his part, the DG has to produce a performance contract (contrat d'objectifs), which presents his vision for the operationalisation of the political mandate and details of concrete actions arising from his strategy. [[edits OK?]] The aim of this 'translation process' is to enable better operationalisation by the administration of the political will. By doing so, the administration remains the executor of the political will. The goals it has to achieve are clear and feasible and the political authority can have a better view of the degree of implementation of its goals. This concept of contract is quite new for the DG and is a sign of greater cooperation between the political bodies and the administration (through the DG). In practice, very few such contracts have been completed and signed so far.

Moreover, the reform has resulted in the establishment of an executive committee (comité de direction) in charge of organisational and operational issues, ensuring transversal communication between services and direct contact with 
the local authorities. It is also charged with ensuring that new human resources (HR) management tools are developed (such as organigrams).

Last but not least, the head of the local administration should ensure that their actions [[whose actions?]] are regularly evaluated, in order to check the quality of management and the degree of realisation of missions and objectives. Evaluations are organised by the political authorities with the support of external experts. ${ }^{6}$ If the evaluation is negative or 'unfavourable', the local council can propose to end the contract with the DG on the basis of professional ineptitude (Durviaux and Fisse, 2015, pp 143-4).

With regard to financial resources, the financial head of administration is obliged to give legal advice on every project with a budget of more than $€ 22,000^{7}$ and on the budgetary aspects of the PST; advice is given at the planning stage, making the projections of the political strategic priorities more realistic. This reform gives the financial head a more active role, transforming the local politico-administrative equilibrium. It is in light of these changes that we study the local policy style in Gembloux.

\section{The case of Gembloux}

Among the 262 Walloon communes, Gembloux is a medium-sized municipality with over 25,000 inhabitants, a steadily rising population that increased by $25 \%$ from 2000 to 2010 . It is a university town, in a rural area, situated between Namur and Brussels. Its increase in size and importance, coupled with the growing complexity of local matters, has left the local authorities facing new challenges such as mobility, land use and impoverishment in the inner centre. It has therefore implemented the three regionals instruments described earlier.

Gembloux adopted a PCDR in 2005 in order to identify and meet the needs of its residents through citizen involvement. The input of inhabitants and stakeholders, as well as the outcomes, were considered to be great achievements. Local stakeholders and citizens were very receptive to the implementation of the PCDR, and the process was characterised by a lack of politicisation. As one of the aldermen stated:

"We have at the participatory level quite some tools where citizens participate in function of their interest but also in function of the associations, lobbies, etc [[meaning unclear]]. This works pretty well because this is not at all politicised or almost not politicised."

The local authorities had introduced participation mechanisms in many areas (such as schools management, social policies and territory planning), but none of them involved the same co-construction dynamics that occurred in the PCDR.

Local authorities seem therefore to have integrated into their policymaking the consensus-seeking style of this tool. Nevertheless, the process was not without its challenges: chiefly, this type of participation is time-consuming. The DG noted 
that: "This is really, really time-consuming to implement. The public consultation of all the villages took us two years. And for little impact on the population". The local authorities were also critical of the fact that the PCDR suffers from inflexibility and a lack of adaptability to an evolving context, especially when the slow pace of the procedure implies that the planned projects will several years to come to fruition. However, Gembloux intends to reiterate the process, which suggests that the potential subsidies, the technical support provided by the region and the participatory and anticipatory dynamics of the PCDR overcome its weaknesses.

Gembloux was also a candidate to be a pilot for the development of a PST (2013-18). Compared with the PCDR, the commune had more freedom to develop the PST. Gembloux used the services of an external consultant for the methods but the content was produced by the local public servants and the political actors themselves. The commune could really adapt the PST to its own vision, and it decided to match the PST to its statement of local policy (déclaration de politique communale), the roadmap agreed by the coalition partners for the six-year term. The compulsory reform of the administration had the effect of formalising existing practice. Limited to organisational issues, the reform reaffirmed the relationship between political and administrative authorities, allowing some room for management by the DG while retaining the decision-making powers of the political authorities. The administration was already organised on the basis of specialised areas whose heads met regularly, forming the executive committee. The DG has to play more of a coordination and management role, but his or her vision of the way the commune should function also has a great influence on the communication between the political and administrative authorities.

The transversal dimension of the PST is recognised and supported by both the political and administrative actors, but their perception of its added value differs somewhat. From the political point of view, the PST is a transversal, complete, flexible, evolving and very useful tool that enables the commune to clearly set priorities while taking the budgetary dimension into account. For the administration, the PST did not bring much added value. While the idea behind the PST is to urge communes to adopt a transversal and strategic vision, Gembloux had already embraced this logic when it gained ISO certification from the International Organization for Standardization in the 2000s. For this reason, the administration perceived the PST as the compulsory duplication of work that did not address the real need, that is, the lack of communication between the political authorities and the administration as well as within the administration. Nevertheless, the PST introduced an evaluation component as well as a new procedure for long-term analysis in resource management and budgeting, forcing the commune to choose its goals for the coming three years.

The case of Gembloux also reveals an increase in the complexity of local responsibilities and the importance of qualified and skilled staff to address this complexity. The ability of the commune to hire professionals such as lawyers and architects for specific areas of activity while maintaining transversal contacts 
and insight is critical. The administration has a duty to carry out the strategic planning function using the regional tools, so the skills of its personnel are as important as the tools. [[edit OK?]] Technical support and HR development are needed to help it gather the necessary competencies for planning and managing more complex projects.

The clear common goal of these - relatively new - tools is to help the communes to face the growing complexity of their jurisdiction through a strategic approach. However, the participatory planning tool (PCDR) has a patent disadvantage: the slow pace and cumbersome nature of procedures and regional control, as well as the amount of human and financial resources needed to develop and follow up such a strategic, bottom-up, diagnosis-based approach. In the light of the case study of Gembloux, the contrast between regional embedded local policies and pure local policies seems to be salient, the latter being achieved much faster but also involving smaller budgetary items and consequently less structural, as it was put at the fore for the PCDR large projects [[sense of final clause?]]. With the two managerial reforms (PST and the 2013 law on the status of heads of staff), the region also tends to impose new policy processes at the local level, with stricter budgetary control, a more strategic management style and a more transversal approach. Evaluation is also being introduced at the local level (with reference to the evaluation of PST and of heads of staff themselves).

\section{Conclusion}

To explore local policy planning in Belgium, this chapter has focused on the country's two largest regions - Flanders and Wallonia respectively. The Flemish and Walloon regional governments have opted to regulate local planning differently. Their central rules and regulations frame local governments' adoption and implementation of a policy plan, but they are not crucial to this end. Indeed, and put differently, local government in both regions still has considerable leeway to decide on specific ways of working when dealing with the needs and desires of its environment and citizens, and involving other local actors. The former may take an anticipatory or reactive approach while the latter may adopt a consensusseeking or coercive stance. This leads us to distinguish four policy styles, whereby local government can plan in a post-modern (that is anticipatory and consensusseeking), communicative (that is reactive and consensus-seeking), strategic (that is anticipatory and coercive) and traditional (that is reactive and coercive) way. These planning styles are not mutually exclusive, as both cases studies have illustrated.

Deinze and Gembloux, which are supposed to be 'business as usual' stories, provide meaningful insights regarding local policy analysis in Belgium. Their different regional frameworks show how municipalities may face regional intervention and the imposition of requirements at the same time as acquiring the ability to broaden their scope of action. Greater breadth of action and more complex policy fields call for higher levels of competence in local administration. In the current times of budget restrictions, especially in the case of small 
municipalities, these conditions are likely to set a trend for the pooling of relevant competencies across municipalities as well as the reinforcement of networks with surroundings communes. [[edit OK?]]

Our case study of Deinze shows that the city initially chose a communicative style but consciously opted to complement it with a more strategic way of working in the later executive phases of the planning process. Clearly, this observation points to Flemish local government's capacity and flexibility when it comes to analysing policy. Deinze has been shown to deal with its environment in an anticipatory as well as a reactive way and to involve citizens in a consensus-seeking as well as a more coercive fashion. This finding urges us to extend our typology of policy styles. The case of Deinze case illustrates the necessity to consider at least one combination type of communicative and strategic policy style in order to empirically grasp planning practice.

In Wallonia, the government has established different tools outlining different policy styles. Two of these tools have been used in Gembloux. With the introduction of PCDR, policy content is mainly co-constructed by the nonpolitical actors, on the basis of a thorough diagnosis of the state of affairs in the local environment and an anticipatory approach declining [[defining?]] the long-term objectives as a ten-year vision. The PCDR reveals a consensus-seeking and anticipatory approach that is valued by the local authorities: this style, and the participatory dynamics involved, were fruitful but considered by the local authorities to be very time-consuming. The other main tool is the more recent PST, a comprehensive tool linking ambitious strategies to specific actions. In terms of policy style - designing the policy process without involving citizens - it may be regarded as coercive, and it aligns local policy analysis with a process-oriented style. Yet, it can be argued that it has more to do with rationalisation of implementation (with regard to the means of action) and with the modernisation of local public services than with actual definition of policies. The PST focuses chiefly on the implementation of policy goals by translating them into operational actions and on their assessment and adjustment in line with available means and resources. This new tool, proposed by the regional authorities to support local reforms in policy style, suggests a more coercive policy style. [[edits OK in this para?]]

The insights from the two local case studies reveal the importance of the regional framework, which provides opportunities and constraints for policy, as well as retaining elements of local autonomy. This study has shown that there are possibilities for a myriad of policy-analytical planning styles at Belgian's local level, worthy of further research and exploration. The case studies lead us to two new branches in the development of a policy analysis framework. First, proximity at the local level between political authorities, administrations and citizens should be considered specifically in the model design to enrich its explanatory potential [[sense? to make it more accessible?]]. Second, the local level lends itself in particular to the transversal policy approach, where policy analysis in different sectors and with different tools reveals a mix of styles within the same political administrative setting. This typifies local policy analysis regimes. [[edits OK?]] 
Finally, policy styles should give greater attention to relations with higher authorities; in Flanders and Wallonia there appears to be a trend for regional authorities to take back the reins and reduce local autonomy by imposing on local authorities new policy styles in more policy domains and areas of competency, with a view to modernising local government and controlling resources. However, even though their functioning is largely constrained by regulations common to every municipality, each commune is a unique entity in itself, with its own traditions, rules and actors, and consequently with the means to adapt regional policy tools to the local context in their chosen style. [[edits OK?]]

\section{Notes}

1 In Flanders, region and community have been merged. The German-speaking municipalities are part of the Walloon Region for policy matters under the competency of the regions. In Brussels, the Flemish and French Communities are responsible for local issues in their own community, except for those issues that affect both language communities, in which case a Joint Community Commission has competency).

2 There is a public centre for social welfare in every Belgian municipality. It provides social support and fights poverty.

3 To date, the PCDR is not a compulsory tool for the Walloon communes; so far, 92 have adopted a PCDR out of a total of 124 rural communes. More information about the workings of PCDRs is available at www.pcdr.be/operation-de-developpement-rural-odr (accessed on 6 February 2013).

4 The first such PSTs were adopted in 2012 by 24 pilot communes for the 2012-18 legislature.

5 Regional law of 18 April 2013 (Décret du 18 avril 2013 modifiant certaines dispositions du Code de la démocratie locale et de la décentralisation) and a second regional law of 18 April 2013 (Décret du 18 avril 2013 modifiant certaines dispositions de la loi du 8 juillet 1976 organique des centres publics d'action sociale).

6 Decree of the Walloon government of 11 July 2013 (Arrêté du Gouvernement wallon du 11 juillet 2013 fixant les règles d'évaluation des emplois de directeur général, directeur général adjoint et directeur financier communaux), art. $4, \$ 6$.

7 CDLD, art. L1124-40, $\$ 1 \mathrm{er}, 3^{\circ}$.

\section{References}

Bouhon, F., Niessen, C. and Reuchamps, M. (2015) 'La Communauté germanophone après la sixième réforme de l'état: état des lieux, débats et perspectives', Courrier hebdomadaire du CRISP, no. 2266-2267.

Bovens, M., Hart, P. and Peters, B.G. (eds) (2001) Success and failure in public governance, Cheltenham: Edward Elgar.

Boverie, M., Maitre, A. and Van Driessche, L. (2013a) 'Gouvernance - fiche 2 - le PST: programme stratégique transversal communal', in Focus sur la commune - 161 fiches pour une bonne gestion communale, Namur: Union des Villes et Communes de Wallonie.

[[not cited]] Boverie, M., Maitre, A. and Van Driessche, L. (2013b) 'Gouvernance - fiche 3 - le PCS: plan de cohésion sociale', in Focus sur la commune - 161 fiches pour une bonne gestion communale, Namur: Union des Villes et Communes de Wallonie. 
Boverie, M., Maitre, A. and Van Driessche, L. (2013c) 'Gouvernance - fiche 4 - les nouveaux principes de gouvernance locale en Wallonie - la réforme des grades légaux', in Focus sur la commune - 161 fiches pour une bonne gestion communale, Namur: Union des Villes et Communes de Wallonie.

Commissie Efficiënte en Effectieve Overheid (2009) Een slagkrachtige overheid in Vlaanderen, Brussels: Commissie Efficiënte en Effectieve Overheid.

[[not cited]] Commissie Efficiëntiewinst voor de Lokale Besturen (2010) Rapport met aanbevelingen, Brussels: Commissie Efficiëntiewinst voor de Lokale Besturen. [[not cited]] De Bruycker, P. and Philippart, E. (1990) 'Les communes et les provinces dans la Belgique nouvelle', Pouvoirs, 54: 93-110.

Decoster D.P. et al [[list all authors?]] (2003) Vers des contrats d'avenir locaux. Elaborer et réussir sa stratégie de développement communal, Brussels and Liège: ULGIGEAT.

De Rynck, F. and Wayenberg, E. (2009) 'Local government in Flanders, Brussels and Wallonia. Towards more convergence or divergence in Belgian's local government systems?', in E. Page and M. Goldsmith (eds) Central and Local Government Relations, London: Sage Publications, 14-29.

De Rynck, F. and Wayenberg, E. (2013) 'Hoofdstuk 7. De lokale besturen', in A. Hondeghem, W. Van Dooren, F. De Rynck, B. Verschere and S. Op de Beeck (eds) Handboek bestuurskunde, Bruges: Vanden Broele, 191-230.

Deschouwer, K. and Reuchamps, M. (2013) 'The Belgian federation at a crossroad', Regional \& Federal Studies, 23(3): 261-70.

[[not cited]] De Schutter, T. (2013) 'Missions de la commune - fiche 2 - le développement rural', in Focus sur la commune - 161 fiches pour une bonne gestion communale, Namur: Union des Villes et Communes de Wallonie.

Dienst Wetmatiging [[spelling? Wetsmatiging?]] (2007) Administratieve lastenmeting planverplichtingen lokale besturen: finaal rapport, Brussels: Vlaamse Overheid.

Dienst Wetsmatiging (2010) Implementatietraject kaderdecreet planlasten voor lokale besturen, Brussels: Vlaamse Overheid.

Durviaux A.L. and Fisse D. (2015) Droit de la fonction publique locale. Bruxelles, Flandre, Wallonie, Brussels: Larcier.

Dyson, K. (1982) 'West Germany: the search for a rationalist consensus', in J. Richardson (ed) Policy styles in Western Europe, London: Allen \& Unwin, 17-46. Freeman, G.P. (1985) 'National styles and policy sectors: explaining structured variation', Journal of Public Policy, 5(4): 467-96.

Godart, M.F. and Deconinck, M. (2003) 'Développement territorial en milieu rural: quelques exemples en région wallonne', Revue d'économie régionale et urbaine, 5: 909-24.

Knill, C. and Tosun, J. (2008) 'Policy making', in D. Caramani (ed) Comparative politics, Oxford: Oxford University Press, 495-519.

[[not cited]] Maes, R. (ed) (1985) La décentralisation territoriale, situations et perspectives, Brussels: Inbel. 
Matagne, G., Radoux, E. and Verjans, P. (2011) 'La composition du collège communal après la réforme du Code wallon de la démocratie locale', Courrier hebdomadaire du CRISP, no. 2004.

Matland, R.E. (1995) 'Synthesizing the implementation literature: the ambiguityconflict model of policy implementation', Journal of Public Administration Research and Theory, 5(2): 145-74.

Mayer, I.S., Van Daalen, C.E. and Bots, P.W.G. (2004) 'Perspectives on policy analysis: a framework for understanding and design', International Journal Technology, Policy and Management, 4(1): 169-91.

Parsons, W. (ed) (1995) Public policy, Aldershot: Edward Elgar.

Radin, B.A. (ed) (2000) Beyond Machiavelli: policy analysis comes of age, Washington, DC: Georgetown University Press.

[[not cited]] Reuchamps, M. (2013) 'The current challenges of Belgian federalism and the sixth reform of the state', in A. López-Basaguren and L. Escajedo San-Epifanio (eds) The ways of federalism in Western countries and the horizons of territorial autonomy in Spain, Heidelberg: Springer, 375-92.

Richardson, J., Gustafsson, G. and Jordan, G. (1982) 'The concept of policy style', in J. Richardson (ed) Policy styles in Western Europe, London: Allen \& Unwin, 1-16.

[[not cited]] Ropars, G. and Hermand, C. (2006) Résultats de l'enquête réalisée auprès des pouvoir locaux de la Région wallonne en vue de connaitre leurs initiatives en termes de réflexion sur le futur, Namur: Intelligence territoriale wallonne.

[[not cited]] Stad Deinze (2014a) Financiële nota 2014-2019, Deinze: Stad Deinze.

[[not cited]] Stad Deinze (2014b) Meerjarenplanning 2014-2019, Deinze: Stad Deinze.

Union des Villes et Communes de Wallonie (2011) 'Le programme stratégique transversal communal (PST) Une démarche stratégique pour les villes et communes', Mouvement Communal, 863 (hors-série).

Van Cauwenberghe J.-C. (2003), 'Préface', in D.P. Decoster et al [[list all eds?]] (eds) Vers des contrats d'avenir locaux. Élaborer et réussir sa stratégie de développement communal, Brussels and Liège: ULG-IGEAT.

Van Overmeire, K. (2013) 'La situation financière des communes wallonnes', Mouvement communal, 6: 21-26.

Vlaamse Regering (1995) De Vlaamse Regering 1995-1999. Bakens voor de 21ste eeuw, Brussels: Vlaamse Overheid.

Vlaamse Regering (1999) De Vlaamse Regering 1999-2004. Een nieuw project voor Vlaanderen, Brussels: Vlaamse Overheid.

Vlaamse Regering (2004) De Vlaamse Regering 2004-2009, Vertrouwen geven, verantwoordelijkheid nemen, Brussels: Vlaamse Overheid.

Vlaamse Regering (2006) Inventaris Vlaamse regering planningslasten lokale besturen en provincies, Brussels: Vlaamse Regering. [[OK? or Vlaamse Overheid? Cf refs above and below]] 
Vlaamse Regering (2009) De Vlaamse Regering 2009-2014. Een daadkrachtig Vlaanderen in beslissende tijden. Voor een vernieuwende, duurzame en warme samenleving, Brussels: Vlaamse Overheid.

Vlaamse Regering (2010) 'Besluit van de Vlaamse Regering van 25 juni 2010 betreffende de beleids- en beheerscyclus van de gemeenten, de provincies en de openbare centra voor maatschappelijk welzijn', Belgisch Staatsblad, 7 October.

Vlaamse Regering (2011) 'Decreet van de Vlaamse Regering van 15 juli 2011 houdende vaststelling van de algemene regels waaronder in de Vlaamse Gemeenschap en het Vlaamse Gewest periodieke plan- en rapporteringsverplichtingen aan lokale besturen kunnen worden opgelegd', Belgisch Staatsblad, 11 August.

VVSG (Association of the Flemish Municipalities) (2006) Inventaris plannen lokale besturen, Brussels: VVSG.

Wayenberg, E., De Rynck, F., Steyvers, K. and Pilet, J.-B. (2010) 'Belgium: a tale of regional divergence', in F. Hendriks, A. Lidstrom and J. Loughlin (eds) The Oxford handbook of local and regional democracy in Europe, Oxford: Oxford University Press, 71-95.

Walloon parliament (2012-2013) Projet de décret modifiant certaines dispositions $d u$ Code de la démocratie locale et de la décentralisation, Exposé des motifs, Parl. w., sess. ord. 2012-2013, n744/1.

Walloon parliament (2013), 